The fibres are elongated in the direction of the $b$ axis, and show very strong pleochroism.

A. F. Hallimond and F. R. Ennos: On Stilpnomelane from North Wales. A dark, scaly vein-mineral, strongly resembling biotite, proves on analysis to contain very little potash, and is very similar in physical properties to stilpnomelane from Moravia. The composition agrees with the formula $6 \mathrm{SiO}_{2} \cdot 2 \mathrm{Fe}_{2} \mathrm{O}_{3} \cdot 2 \mathrm{FeO}$. $3 \mathrm{H}_{2} \mathrm{O}$, Sp.G. 2.85. Apparently uniaxial $; 0=1 \cdot 687, \mathrm{e}=1.595$. Pleochroic, $\quad \mathrm{o}=$ dark brown, $\mathrm{e}=$ pale yellow. Brittle, with eminent basal cleavage and marked cleavage normal to this, yielding pleochroic chips. $\mathrm{H} .=3 \cdot 5$. Insoluble in hot $\mathrm{N} / 2 \mathrm{HCl}$.

Dr. G. T. Prior: On the chemical composition of the Ashdon meteorite : This meteoric stone, which fell at Ashdon, near Saffron Walden, Essex, on 9th March, 1923, is a white hypersthene-chondrite containing $8 \frac{1}{4}$ per cent of nickeliferous iron in which the ratio of iron to nickel is about 6 .

\title{
CORRESPONDENCE.
}

\section{THE SHELL OF CORNULITES.}

Sir,--In June, 1923, Dr. Cowper Reed described certain shells, which he referred to Cornulites, as having an "imbricating segmental structure", and spoke of "the segmented nature of these shells" as placing them in the Annelida tubicola (GEoL. Mag., Vol. LX, p. 271). In December, 1923, I quoted the latter sentence verbatim, and said that it was not clear, but that anyhow the shell of Cornulites serpularius was not segmented; and I gave enlarged figures (accompanied by a scale which Dr. Reed seems to have overlooked) to show the absolute continuity of the structure (Geol. Mag., Vol. LX, p. 542). In your January number (p. 48) Dr. Reed says he has long known this structure. It follows, therefore, that he uses the term "segmented" in a sense that is certainly unusual in scientific writing, if not peculiar to himself.

In both editions of the "Guide to the Fossil Invertebrate Animals ... in the British Museum " (1907 and 1911) Cornulites was left in the Polychoeta tubicola, and my paper tried, though ineffectively, it seems, to warn readers against supposing that I saw reason for removing it from that Suborder.

10th January, 1924.

F. A. Bather. 